\title{
NATURAL MONUMENTS AND MONUMENTAL TREES IN THE OBORNIKI AND RYCZYWÓŁ COMMUNES (WIELKOPOLSKA VOIVODESHIP)
}

\author{
Wojciech AntKowiak, Justyna Ludian \\ W. Antkowiak, Department of Botany, Poznań University of Life Sciences, Wojska Polskiego 71 C, 60-625 \\ Poznań, Poland, e-mail: antkowiak@up.poznan.pl
}

(Received: October 12, 2016. Accepted: December 22, 2016)

\begin{abstract}
In 2010 in the Oborniki and Ryczywół communes a total of 110 trees-natural monuments, seven tree clusters and one avenue were inventoried, while no monuments of inanimate nature were reported in the area of the study. The survey covered jointly 167 trees of 26 species. The largest number of trees protected as natural monuments were sessile oaks Quercus petraea (28 trees) and English oaks Quercus robur (20). Most trees were of a good health condition. A total of 69 trees had healthy stems and 74 trees had healthy crowns. Among the inventoried trees 11 were dead.
\end{abstract}

KEY WORDS: natural monuments, Oborniki, Ryczywól, survey

\section{INTRODUCTION}

Natural monuments as the most numerous group of nature protection forms constitute an important element in the environmental protection system. They are valuable not only thanks to their monumental dimensions and shapes affecting the entire landscape, but they are also valuable material ensuring the continuity of nature heritage, including preservation of biodiversity (HARABIN 1996). Natural monuments need to be passed on to the future generations. The preservation function served by these monuments makes it possible to maintain genetic diversity, particularly in the case of old trees. The presence of aged, monumental trees together with the accompanying vegetation supplies a large body of information on the productivity of habitats and natural development trends. It is also a remnant of natural vegetation and the old age of trees may also show good adaptability of species to existing habitat conditions (OLACZEK 1978). Monumental trees are also monuments of culture, objects of anthropological, dendrochronological or bioindication studies.

\section{THE STUDY AREA, MATERIAL AND METHODS}

A survey of natural monuments was conducted in 2010 in the Oborniki and Ryczywół communes of the Oborniki county (Fig. 1). Natural monuments were inventoried based on information collected from the Regional Environmental Protection Directorate in Poznań and from commune offices.

Trees were inventoried by measuring their trunk circumferences at the height of $1.3 \mathrm{~m}$, accurate to 1 $\mathrm{cm}$. If a tree was located on a slope, its trunk circumference was measured from the side of the slope. Tree height was measured using a hypsometer by Suunto and recorded accurate to $0.5 \mathrm{~m}$.

Health condition of the trunk and crown was assessed in the scale proposed by PACYNIAK \& SMÓLSKI (1973):

- grade 1 (very good health condition) - completely healthy trees, with no dry damage or pest presence,

- grade 2 (good) - trees with partly dying twigs in apical parts of the crown, with the presence of plant or animal pests,

- grade 3 (medium) - trees, which have 50\% dead crown and bole or stem, trees infested by pests to a considerable degree, 


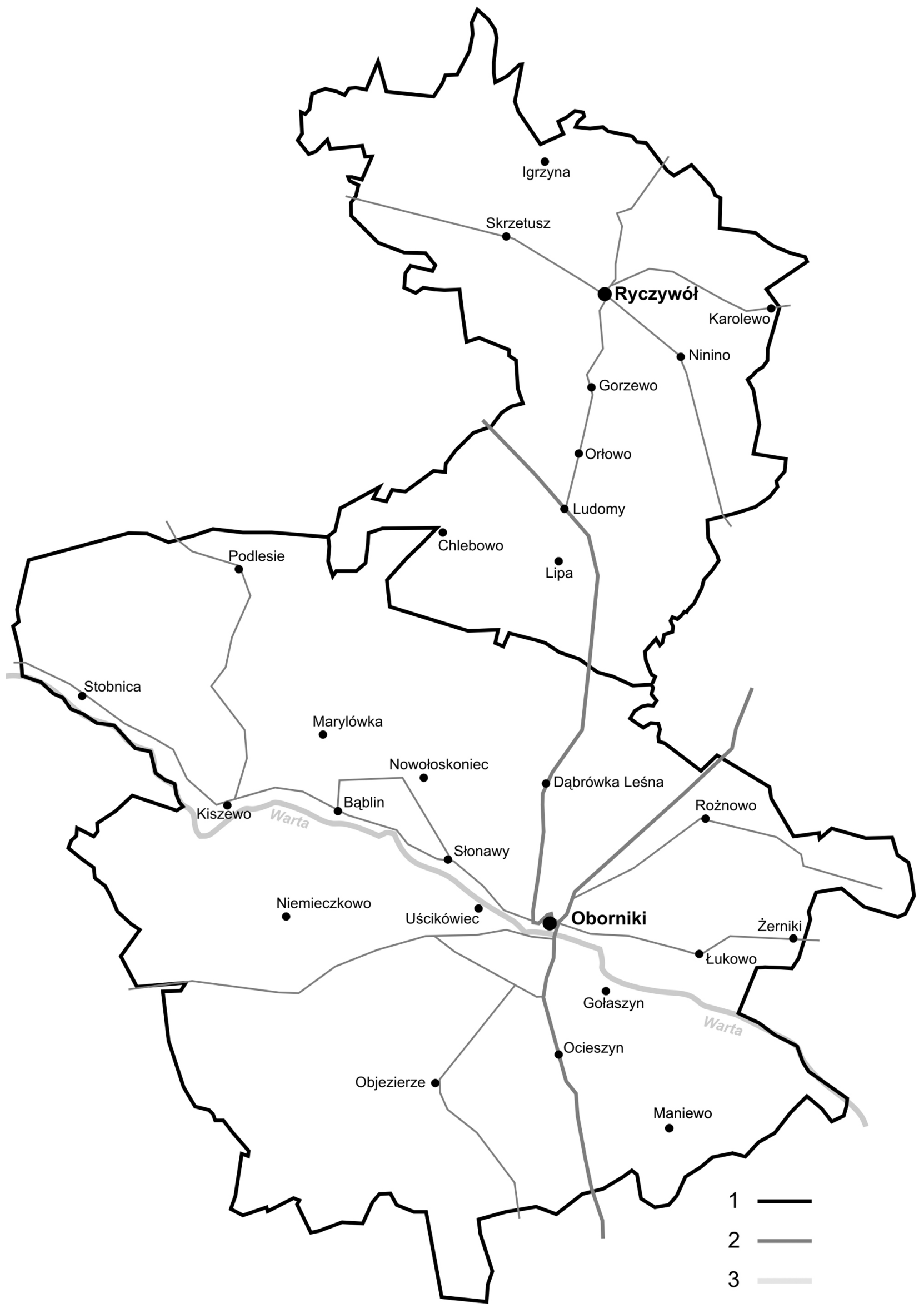

Fig. 1. Locations with natural monuments: 1 - boundaries of communes, 2 - roads, 3 - water bodies 
- grade 4 (poor) - trees having $70 \%$ dead crown and bole or stem, considerable xylem losses,

- grade 5 (very bad) - trees having over $70 \%$ dead crown and bole or stem, with numerous holes, in which less than $25 \%$ stem circumference perform conductive functions, as well as dead trees.

The GPS position of natural monuments was determined using the car navigation system; in the case of avenues the position was given for the beginning of the tree planting, while for tree clusters it was the location of one of the trees.

Nomenclature for trees was adopted after "Dendrology" by Seneta \& Dolatowski (2008).

Tables 1 and 2 list natural monuments by their locations in communes, and within lists for individual communes they are ordered progressively based on the year they were established as natural monuments.

\section{RESULTS}

Within this study a total of 118 natural monuments were inventoried (Tables 1 and 2): 110 trees (101 in the Oborniki commune and 9 in the Ryczywól commune), seven tree clusters (5 in the Oborniki commune and 2 in the Ryczywól commune) and one avenue composed of 33 honey locust (Gleditsia triacanthos L.) trees in the Oborniki commune. Several natural monuments were not inventoried (due to the insufficient data on their location). These include: 1) a wych elm no. 255/855 from Kowanówko, established a natural monument on 17.02.1997, 2-4) a Norway maple no. 260/861, a European white elm no. 262/863 and a small-leaved lime no. 263/864 all from Rożnowo, established natural monuments on $26.08 .1969,5)$ a Norway maple from Oborniki, growing in compartment $855 \mathrm{a}$, established a natural monument on 28.02.2007.

In the case of the English oak no. 256/857 from Stobnica, established a natural monument on 26.08.1969 and a cluster of two European ashes no. 265/866 from Łukowo, established a natural monument on 26.08.1969 it was determined that those trees had been dead and as a result removed.

Among the 118 inventoried natural monuments there are 167 trees, with 25 of them included in seven groups (5.9\% natural monuments).

Among all the inventoried trees 11 are dead. The health status of the trunk or bole was very bad in seven trees, in eight it was bad, in the case of 47 it was medium, in 69 it was good, while 25 trees were characterised by a very good health condition.

A very bad health condition of the crown was recorded in six trees, in 11 it was bad, in 44 - medium, in 74 - good, whereas a very good health condition of the crown was recorded in 21 trees. In the case of avenues the overall health condition of trees was assessed as medium. One of the avenue trees is dead and should be removed for safety reasons.
The inventoried trees-natural monuments belong to 26 species, of which 19 are native. The most numerously represented species are sessile oaks Quercus petraea (Mattuschka) Liebl. (28 trees) and English oaks Quercus robur L. (20 trees). Clusters are most frequently formed by small-leaved limes Tilia cordata Mill. (8 cluster natural monuments with $17 \mathrm{Ti}$ lia specimens). Honey locust Gleditsia triacanthos L., forming a single-species avenue of 33 trees, was the most numerously represented alien species.

Natural monuments are found both on stateowned land and private premises. State-owned land includes land administered by the State Forests with 73 trees $(61.9 \%)$, land belonging to local government units, with a total of 10 trees $(8.5 \%)$, land of the Agricultural Schools in Objezierze (14 natural monuments accounting for $11.9 \%$ of the total), land of the Agricultural Property Agency in Piła with four trees $(3.4 \%)$. One tree is growing in the premises of the parish in Rożnowo. The other natural monuments 16 trees $(13.6 \%)$ are found on private land.

Among all the natural monuments 74 (62.7\%) were established by the provincial governor, while 33 (28\%) were established by the commune council. No information was available on the legal basis for the regulations on 11 (9.3\%) trees growing in the Ryczywół commune.

Almost $70 \%$ monuments bear appropriate plaques with information on the status of the object. Among single trees 69 bear a plaque of NATURAL MONUMENT, while among clusters three are properly marked, whereas the avenue is not marked.

Of all the inventoried natural monuments the thickest tree is an English oak no. 648/131 from Rożnowo, with a circumference of $802 \mathrm{~cm}$. Apart from that in the Rożnowo park there are four trees-natural monuments, which also have impressive dimensions. It is a London plane tree with a circumference of 670 cm (no. 258/859), a Norway maple with $348 \mathrm{~cm}$ in circumference (no. 259/860), a European white elm $-436 \mathrm{~cm}$ (no. 261/862) and an English oak - $519 \mathrm{~cm}$ (no. 264/865).

Another impressive English oak (no. 574, the Ryczywół commune) has a circumference of $694 \mathrm{~cm}$, while that growing in the military training grounds in Biedrusko (no. 1108, the Oborniki commune) has a circumference of $680 \mathrm{~cm}$. We need to mention here an impressive horse chestnut tree (no. 2007/12, the Oborniki commune), which circumference is $421 \mathrm{~cm}$.

In Stobnica there are as many as 40 trees established as natural monuments. At the didactic trail along the Kończak river there are monuments nos. 1109-1146, 227 and 228. Compartment 406h (the Podlesie forest district) is special in this respect, as having high landscape value and the largest number of trees-natural monuments. 


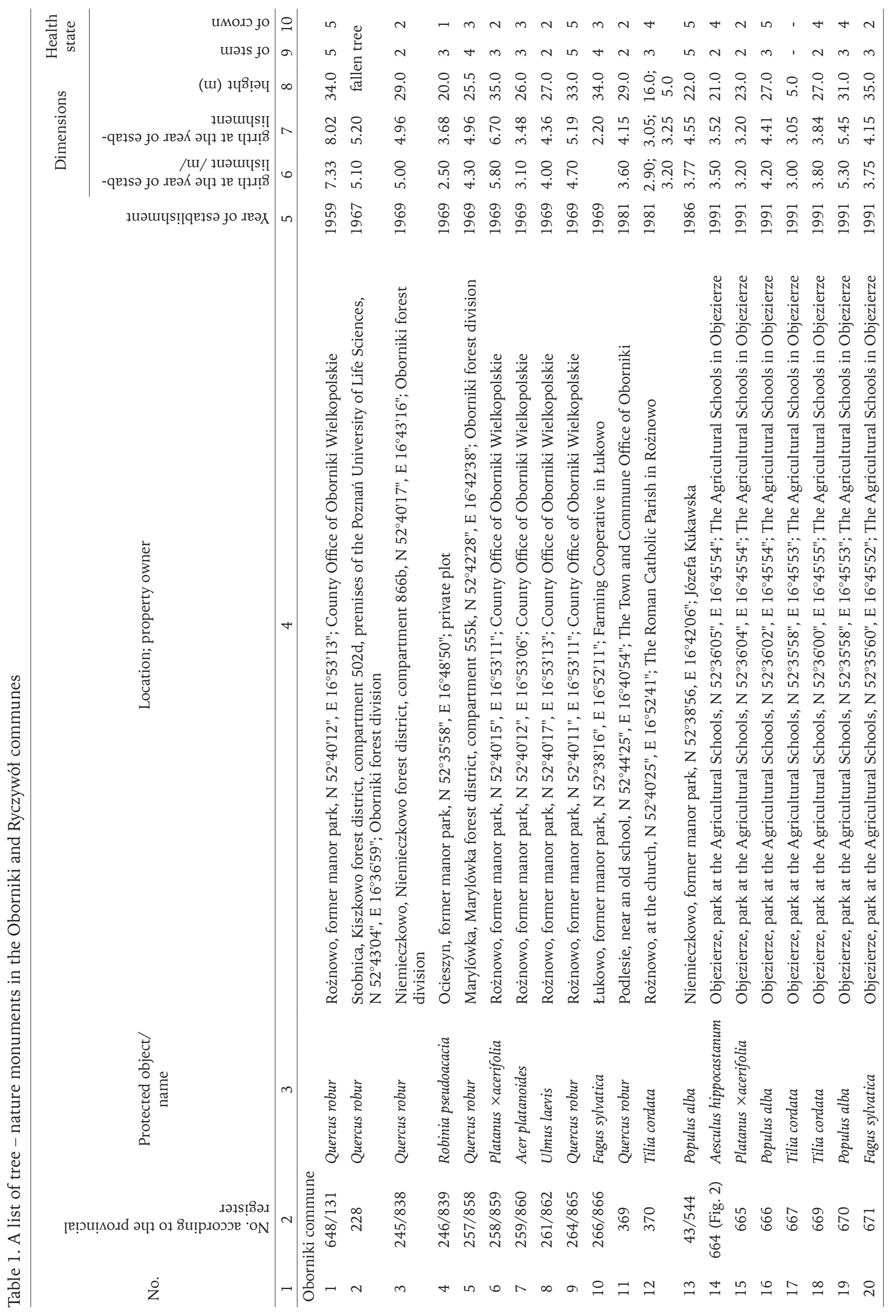




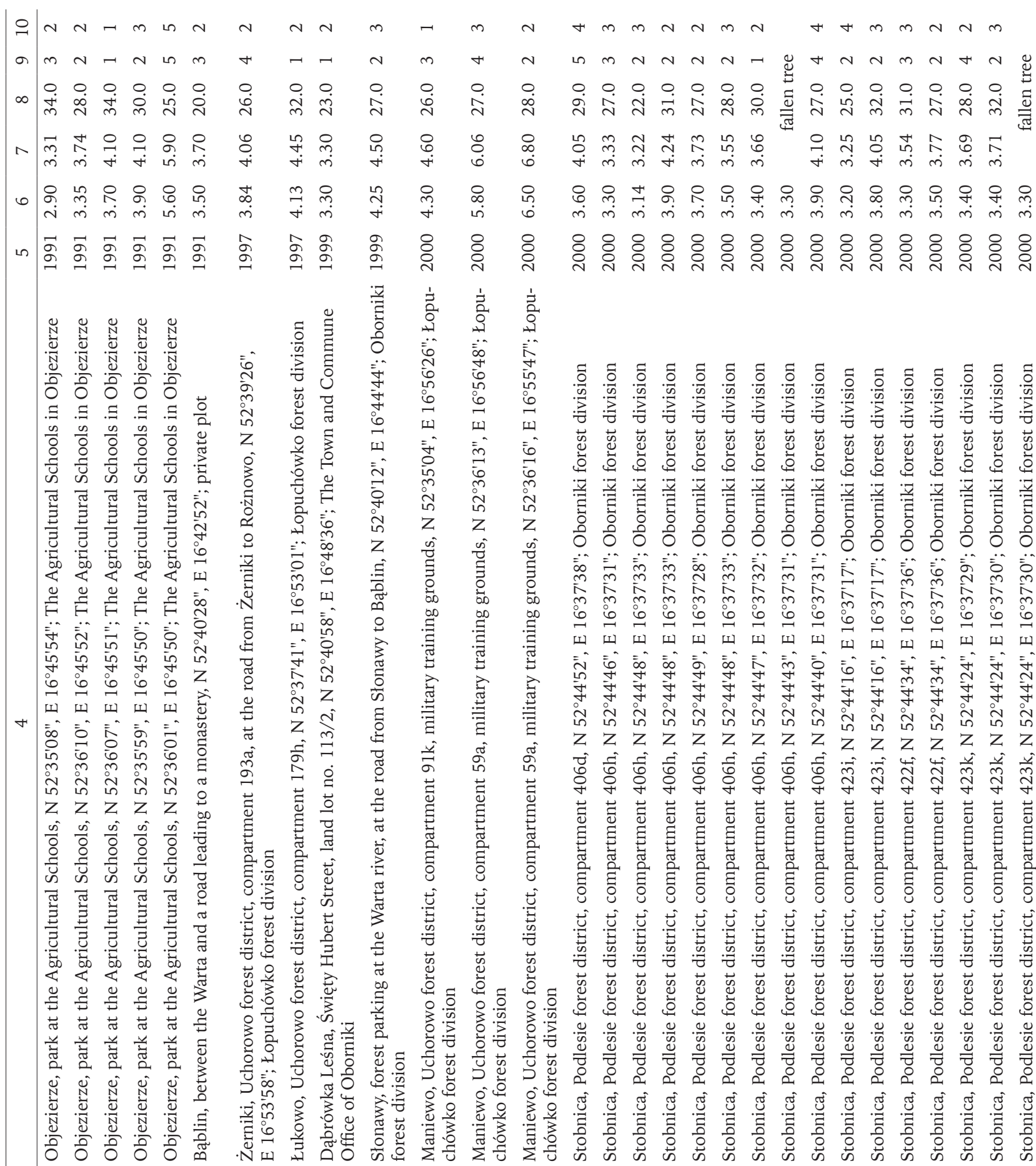

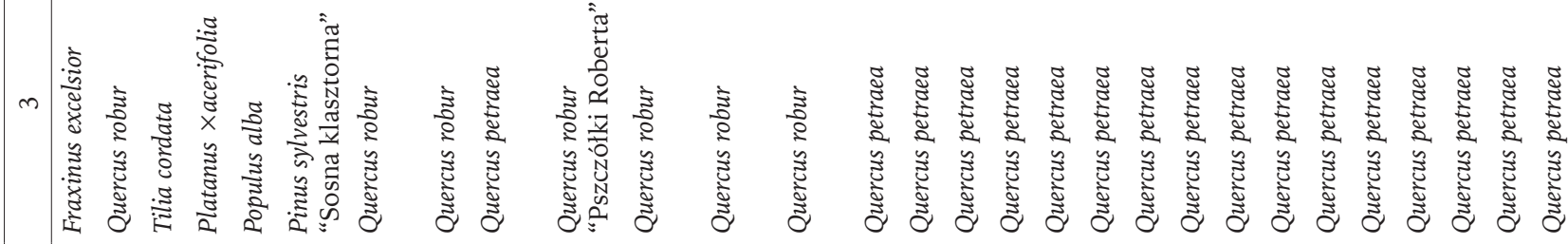

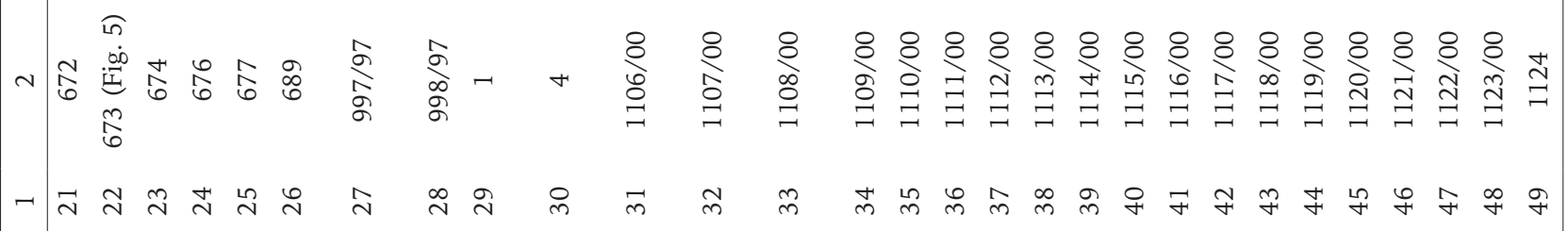




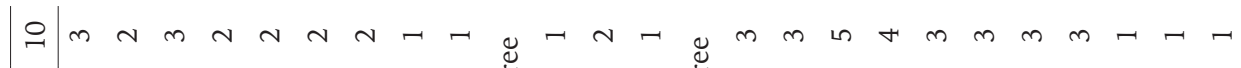
$a m n m n$ n n n n n

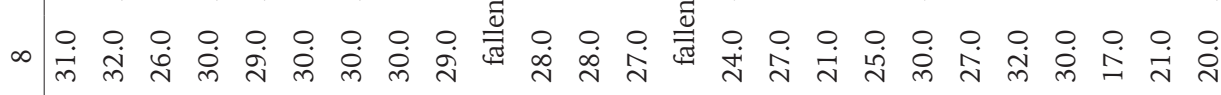

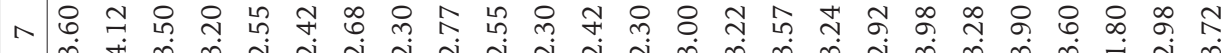

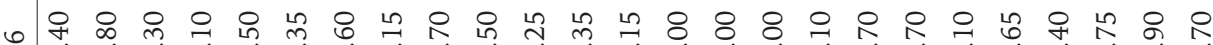

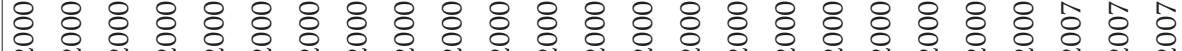

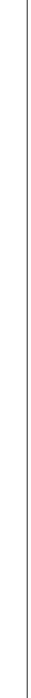

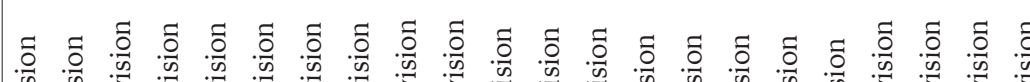

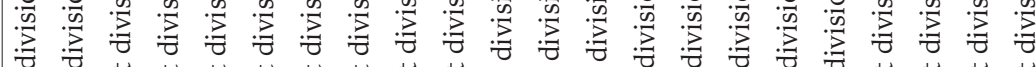

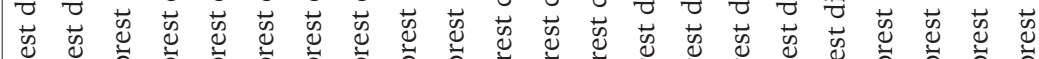

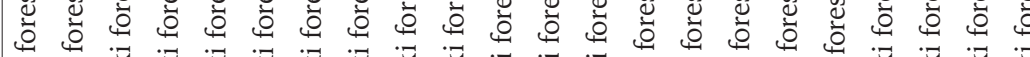

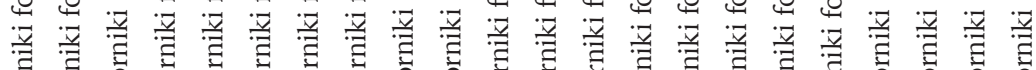

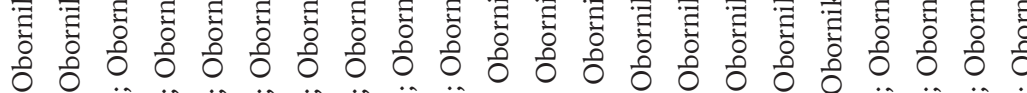

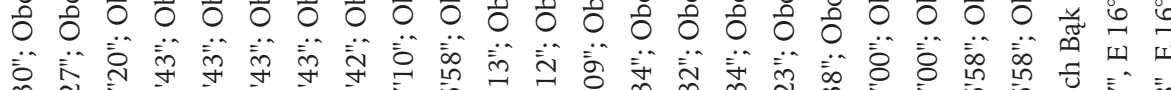

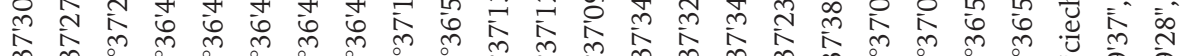

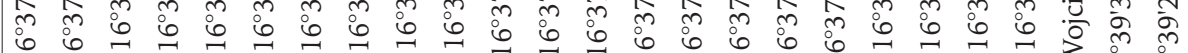

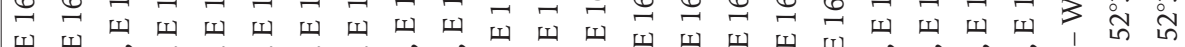

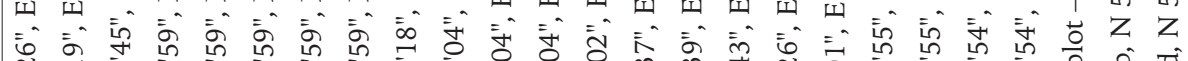

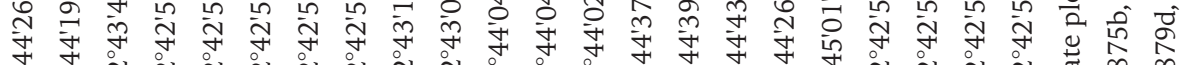
$+\cdots$

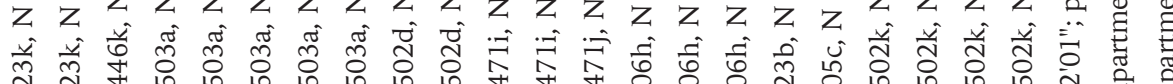
भु भ f

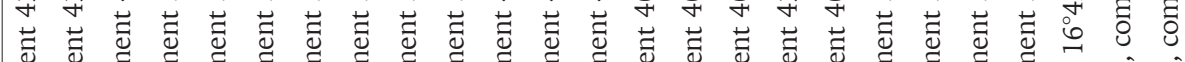

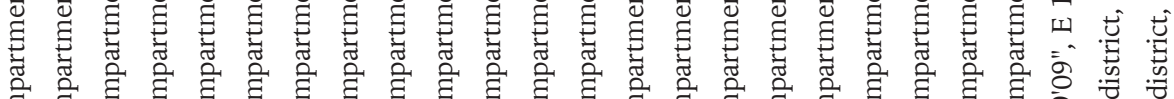
言 范

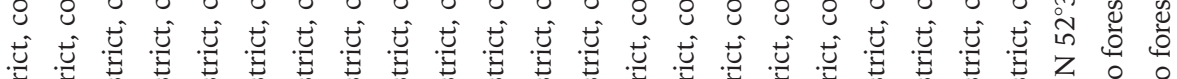

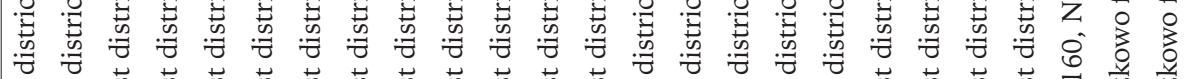

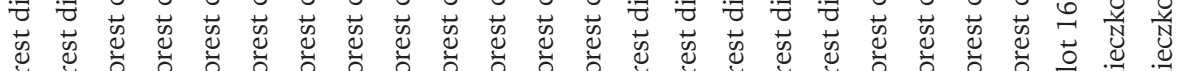

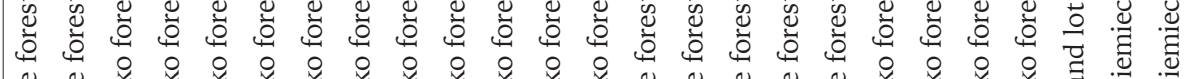

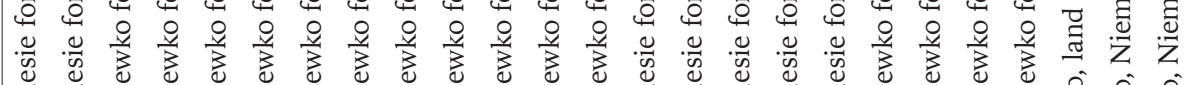

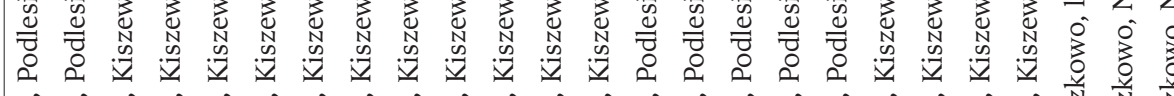

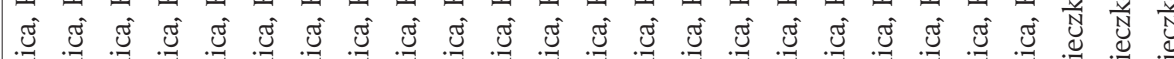

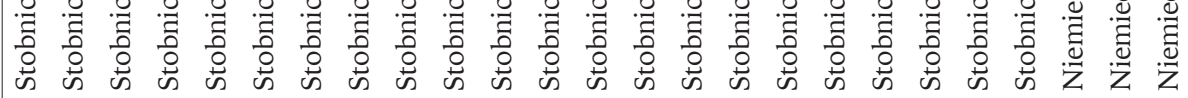
$m n n N m n$

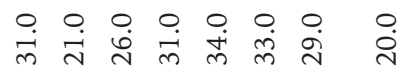

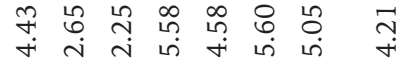
암

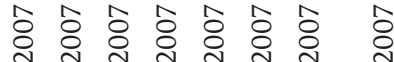
5 :

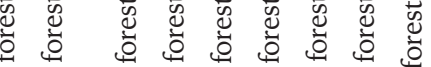

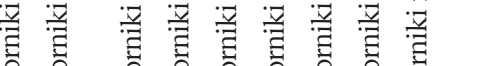

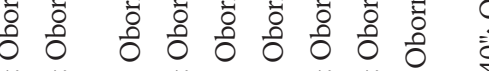

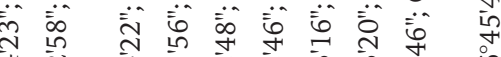

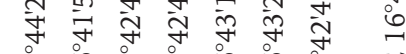

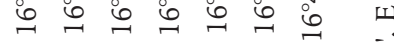

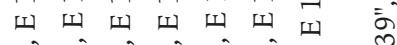
กิ่

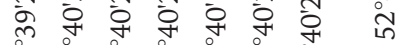
iิ $z z z z z z z$ ij

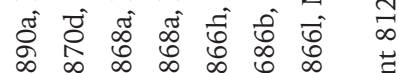

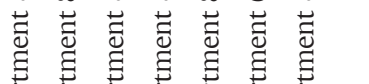
造

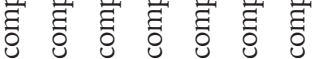

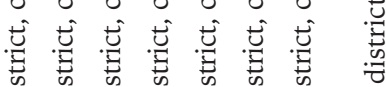

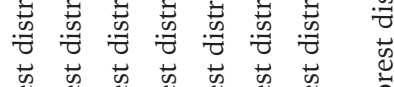

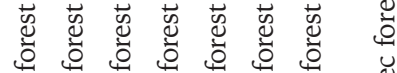

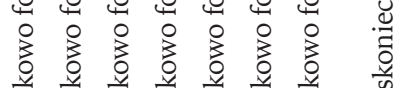

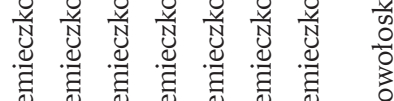

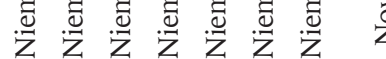

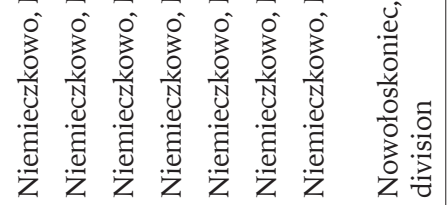

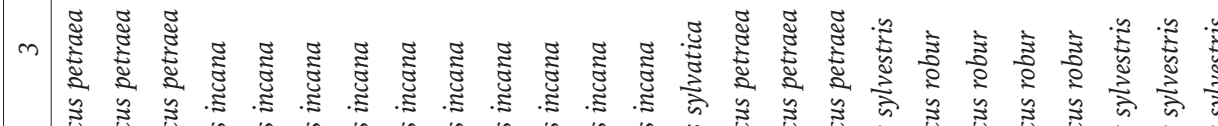

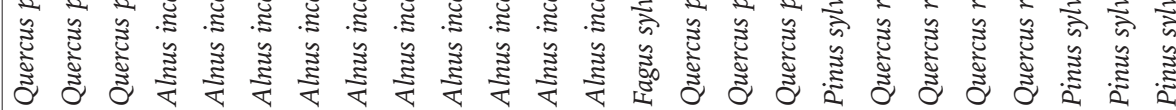

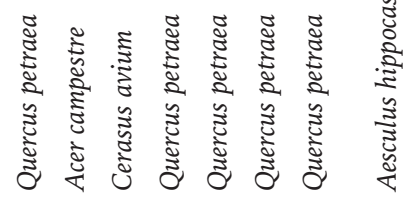
৪ ৪ ৪ ৪ ৪ ৪ ৪ ৪ ৪ ৪ ৪ ৪ ৪ ৪

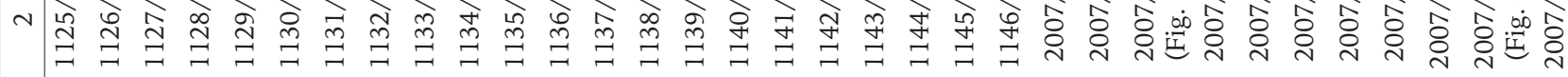
$\rightarrow$ 드느ํ 


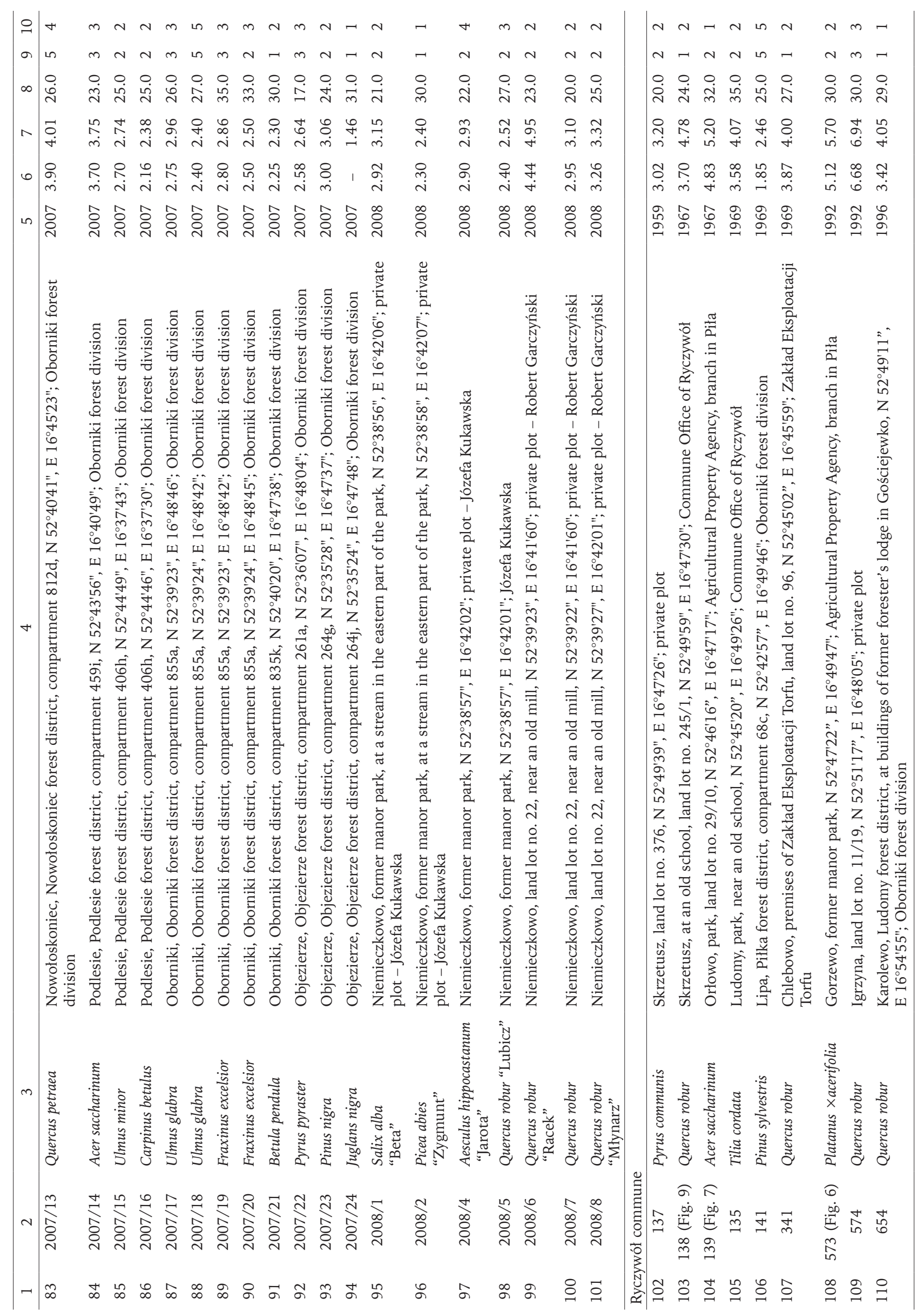


Table 2. A list of tree clusters and avenues - nature monuments in Oborniki and Ryczywół communes

\begin{tabular}{|c|c|c|c|c|c|c|c|c|c|}
\hline \multirow[b]{2}{*}{ No. } & \multirow{2}{*}{ 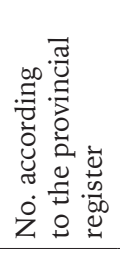 } & \multirow{2}{*}{ 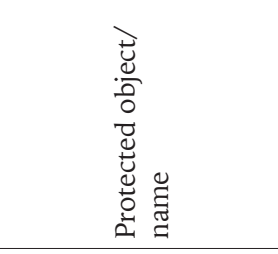 } & \multirow[b]{2}{*}{ Location; property owner } & \multirow{2}{*}{ 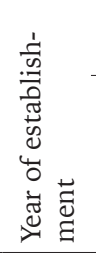 } & \multicolumn{3}{|c|}{ Dimensions } & \multicolumn{2}{|c|}{$\begin{array}{l}\text { Health } \\
\text { state }\end{array}$} \\
\hline & & & & & 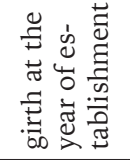 & 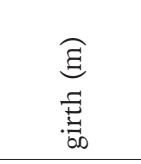 & 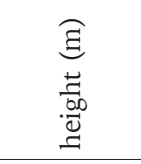 & 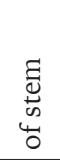 & 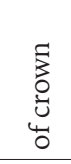 \\
\hline \multicolumn{10}{|c|}{ Oborniki commune } \\
\hline 1 & 227 & $\begin{array}{l}6 \text { Pinus sylvestris } \\
\text { "Stobnickie Babki" }\end{array}$ & $\begin{array}{l}\text { Stobnica, Niemieczkowo forest dis- } \\
\text { trict, compartment } 502 \mathrm{f} \text {, N } 52^{\circ} 43^{\prime} 03^{\prime \prime} \text {, } \\
\text { E } 16^{\circ} 36^{\prime} 58^{\prime \prime} \text {; Oborniki forest division }\end{array}$ & 1967 & $1.6-3.00$ & $1.80-3.10$ & $24.0-26.0$ & $3-2$ & $3-2$ \\
\hline 2 & 430 & $\begin{array}{l}\text { Avenue, } 33 \text { Gleditsia } \\
\text { triacanthos }\end{array}$ & $\begin{array}{l}\text { Commune road Gołaszyn - Oborniki, } \\
\text { N } 52^{\circ} 38^{\prime} 18^{\prime \prime}, \text { E } 16^{\circ} 49^{\prime} 34^{\prime \prime}\end{array}$ & 1983 & $\begin{array}{c}0.45- \\
1.30\end{array}$ & $0.55-1.70$ & $6.0-15.0$ & $5-2$ & $5-2$ \\
\hline 3 & 668 & 5 Tilia cordata & $\begin{array}{l}\text { Objezierze, park at the Agricultural } \\
\text { Schools, N } 52^{\circ} 36^{\prime} 02^{\prime \prime}, \text { E } 16^{\circ} 45^{\prime} 54^{\prime \prime} \text {; The } \\
\text { Agricultural Schools in Objezierze }\end{array}$ & 1991 & $2.2-3.65$ & $2.74-4.03$ & $21.0-32.0$ & $3-2$ & 2 \\
\hline 4 & 675 & 4 Tilia cordata & $\begin{array}{l}\text { Objezierze, park at the Agricultural } \\
\text { Schools, N } 52^{\circ} 36^{\prime} 08^{\prime \prime}, \text { E } 16^{\circ} 45^{\prime} 50^{\prime \prime} ; \text { The } \\
\text { Agricultural Schools in Objezierze }\end{array}$ & 1991 & $1.6-3.9$ & $2.44-3.90$ & $14.0-25.0$ & $3-2$ & 2 \\
\hline 5 & $2007 / 2$ & 2 Pyrus communis & $\begin{array}{l}\text { Uścikówiec, Niemieczkowo forest dis- } \\
\text { trict, compartment } 862 \mathrm{w}, \mathrm{N} 52^{\circ} 39^{\prime} 44^{\prime \prime} \\
\text { E } 16^{\circ} 44^{\prime} 30^{\prime \prime} \text {; Oborniki forest division }\end{array}$ & 2007 & $\begin{array}{l}3.10 \text { and } \\
3.20\end{array}$ & $\begin{array}{l}3.15 \text { and } \\
3.30\end{array}$ & $\begin{array}{l}15.5 \text { and } \\
17.0\end{array}$ & 3 & $\begin{array}{c}5 \text { and } \\
4\end{array}$ \\
\hline 6 & $\begin{array}{l}2008 / 3 \\
\text { Fig. } 8\end{array}$ & 3 Picea abies "Prosna" & $\begin{array}{l}\text { Niemieczkowo, former manor park, } \\
\text { N } 52^{\circ} 38^{\prime} 57^{\prime \prime}, \text { E } 16^{\circ} 42^{\prime} 05^{\prime \prime} \text {; private plot - } \\
\text { Józefa Kukawska }\end{array}$ & 2008 & $\begin{array}{l}1.66- \\
2.16\end{array}$ & $1.75-2.30$ & $29.0-32.0$ & 1 & 1 \\
\hline \multicolumn{10}{|c|}{ Ryczywół commune } \\
\hline 7 & 140 & 3 Tilia cordata & $\begin{array}{l}\text { Ninino, park, land lot } 114 / 2 \text {, } \\
\text { N } 52^{\circ} 47^{\prime} 51^{\prime \prime}, \text { E } 16^{\circ} 52^{\prime} 14^{\prime \prime} \text {; Agricultural } \\
\text { Property Agency, branch in Piła }\end{array}$ & 1970 & $\begin{array}{c}3.67- \\
4.72\end{array}$ & $4.05-4.75$ & $2.5-37.0$ & $5-3$ & $5-2$ \\
\hline 8 & $\begin{array}{l}424 \\
\text { Fig. } 10\end{array}$ & $\begin{array}{l}\text { Quercus robur and } \\
\text { Fraxinus excelsior }\end{array}$ & $\begin{array}{l}\text { Gorzewo, former manor park, } \\
\text { N } 52^{\circ} 477^{\prime} 27^{\prime \prime} \text {, E } 16^{\circ} 49^{\prime} 51^{\prime \prime} \text {; N } 52^{\circ} 47^{\prime} 25^{\prime \prime} \text {, } \\
\text { E } 16^{\circ} 49^{\prime} 48^{\prime \prime} \text {; Agricultural Property Agen- } \\
\text { cy, branch in Piła }\end{array}$ & 1985 & $\begin{array}{l}3.63 \text { and } \\
3.56\end{array}$ & $\begin{array}{l}4.30 \text { and } \\
3.90\end{array}$ & $\begin{array}{l}36.0 \text { and } \\
39.0\end{array}$ & 1 & 1 \\
\hline
\end{tabular}

Another interesting location is Objezierze, with a magnificent palace and park complex. In the park there are 14 natural monuments nos. 664-677.

\section{DISCUSSION}

In the early $20^{\text {th }}$ century and in the period between WWI and WWII numerous data appeared on impressive trees, e.g. Conwentz (1904), Pfunl (1904, 1908), Stecki \& Kulesza (1926), Kulesza (1928), STECKI (1928), ŚRodoŃ (1934, 1935a, b, 1937), WoDzIczKo et al. (1938). In several sources we may find information on monumental trees in the study area. For example, Kulesza (1928) mentioned a cluster of common elms of the cork variety Ulmus campestris $\mathrm{f}$. suberosa Ehrh., growing in the Warta valley east of Oborniki (near Kowanówko) with circumferences up to $1.88 \mathrm{~m}$, a wild service tree Sorbus terminalis Crantz. in the Marylówka forest district with a circumference of $78 \mathrm{~cm}$, a broad-leaved lime Tilia platyphyllos Scop. in the Papiernia forest district with a circumference of $4.55 \mathrm{~m}$ and two localities of flowering common ivy Hedera helix L. in forests between Łuków and Szymanków.

WoDziczko et al. (1938) published a list of natural monuments in the Wielkopolska region. They mentioned the same specimens as those given by KuLESZA
(1928) and reported on several new objects of nature value, i.e. several impressive common spruces in a forest on the Warta river in Łuków, an English oak in Gołaszyn, with a diameter of $1.5 \mathrm{~m}$, an English oak from the Marylówka forest district with a circumference of $3.4 \mathrm{~m}$ (this oak is probably the natural monument no. 257/858 and a circumference of 4.96 $\mathrm{m})$. They mentioned locations with old small-leaved limes: Gołaszyn, Ninino, Połajewo, and lime trees growing at a road between Oborniki and Murowana Goślina.

Impressive trees growing in the Ryczywól commune were mentioned by IwANowsKi et al. (1966): eight common junipers Juniperus communis L. growing at a road in Lipa, 20 common junipers from the Ludoma forest district and a common pear Pyrus communis L. growing in Skrzetusz. Among the above-mentioned trees only the pear tree was covered by legal protection and assigned register number 137.

In 2002 a competition for the thickest trees of the State Forests was announced. Over six thousand specimens from throughout Poland were registered. The competition selected the thickest trees of individual species. Several speciments from the forests in the Oborniki Forest Division were leading in the category of the thickest trees. In this respect both natural monuments and monumental trees were in- 


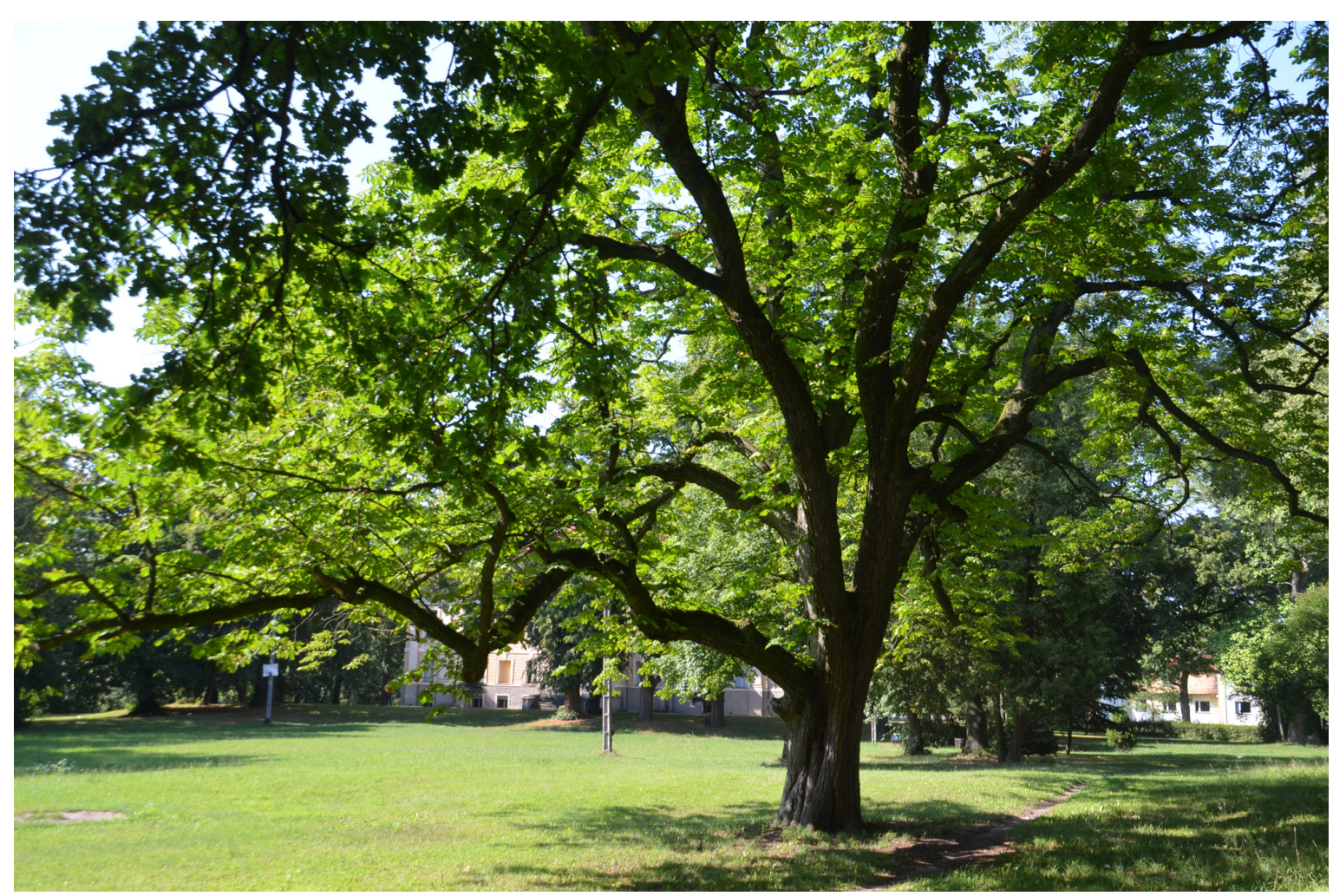

Fig. 2. Horse chestnuts Aesculus hippocastanum in Objezierze (no. 664, the Oborniki commune, circumference $3.52 \mathrm{~m}$ ); photo W. Antkowiak

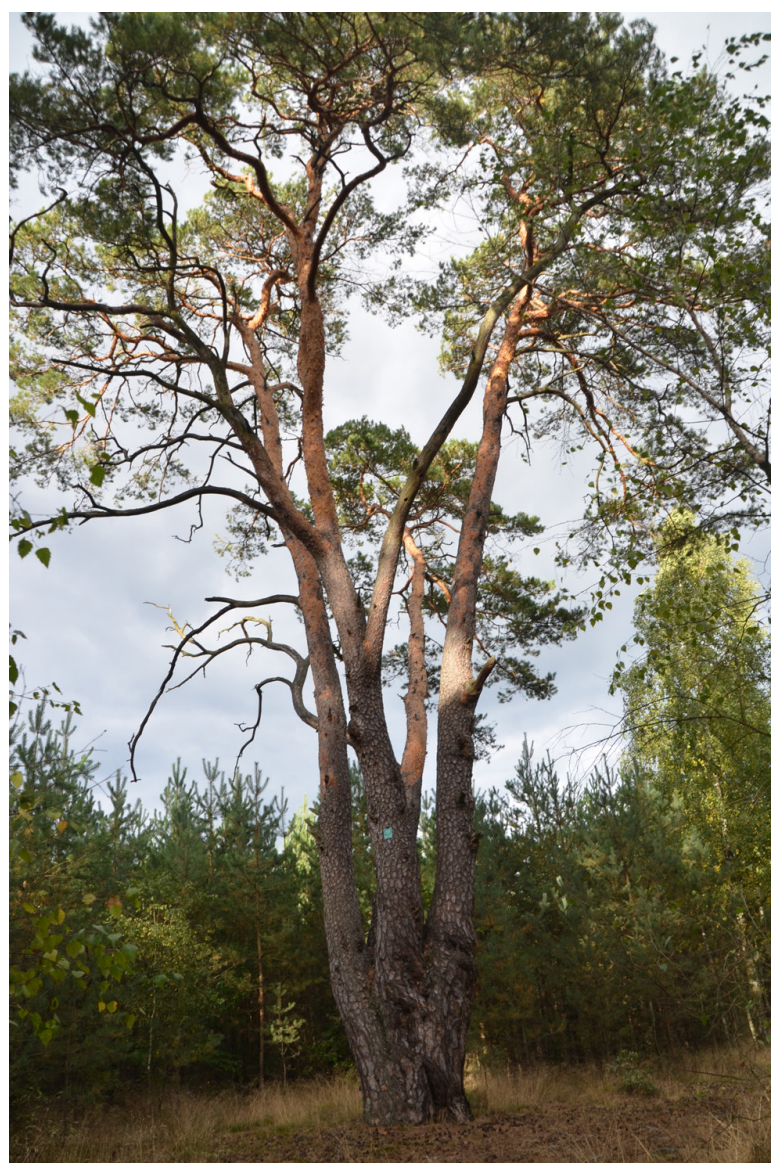

Fig. 3. Pinus sylvestris (no. 2007/4, Niemieczkowo, the Oborniki commune, circumference $3.72 \mathrm{~m}$ ); photo W. Antkowiak

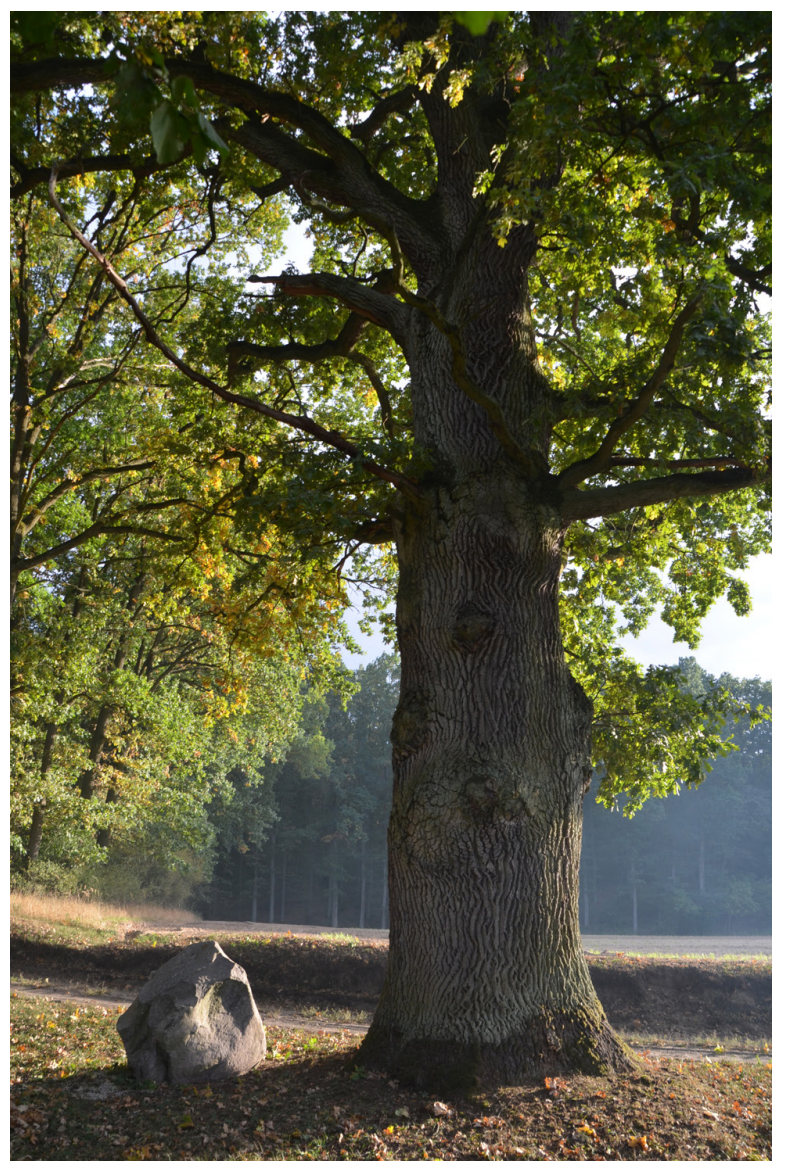

Fig. 4. Quercus petraea (no. 2007/11, Niemieczkowo, the Oborniki commune, circumference $5.05 \mathrm{~m}$ ); photo W. Antkowiak 


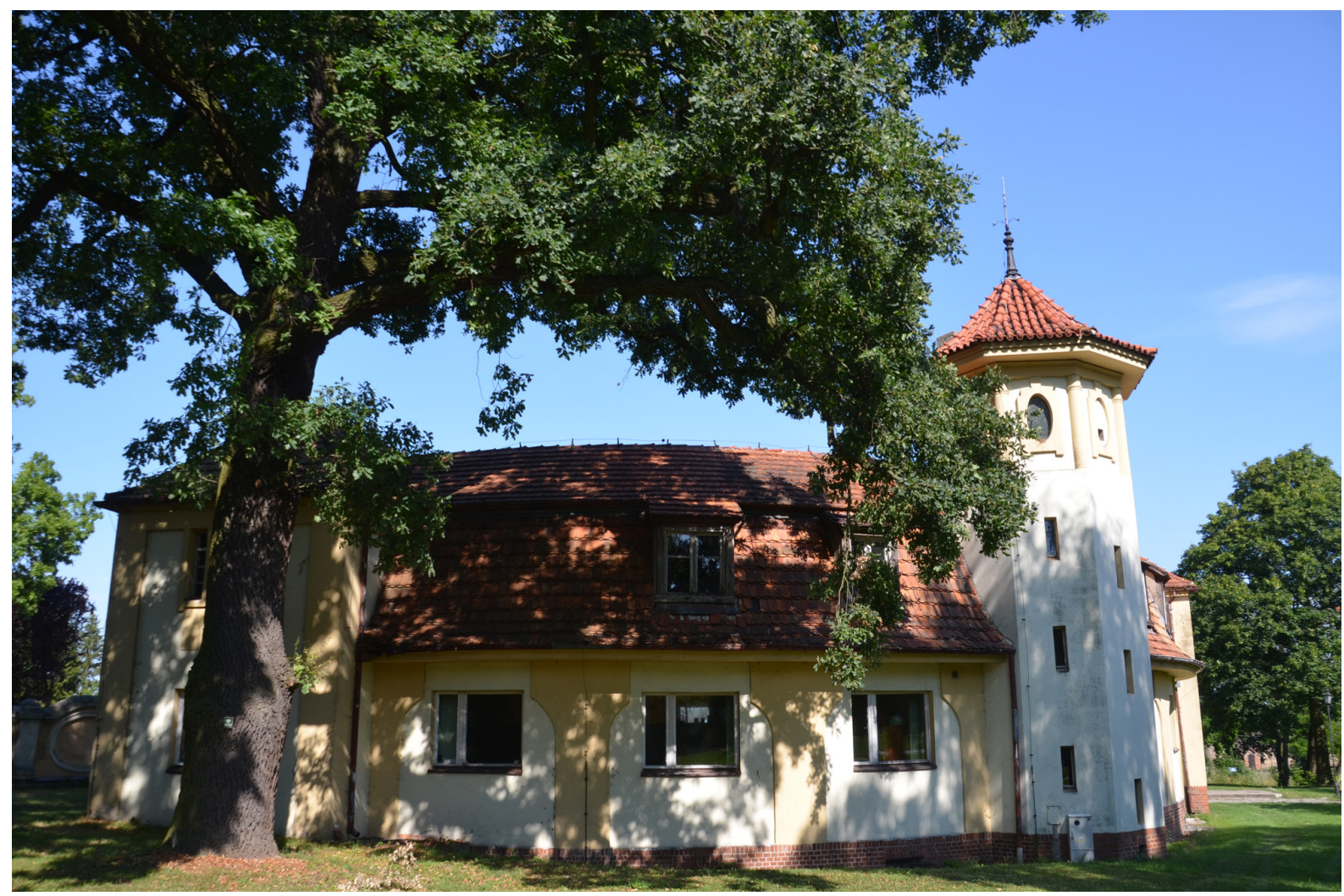

Fig. 5. Quercus robur (no. 673, Objezierze, the Oborniki commune, circumference 3.74 m); photo W. Antkowiak

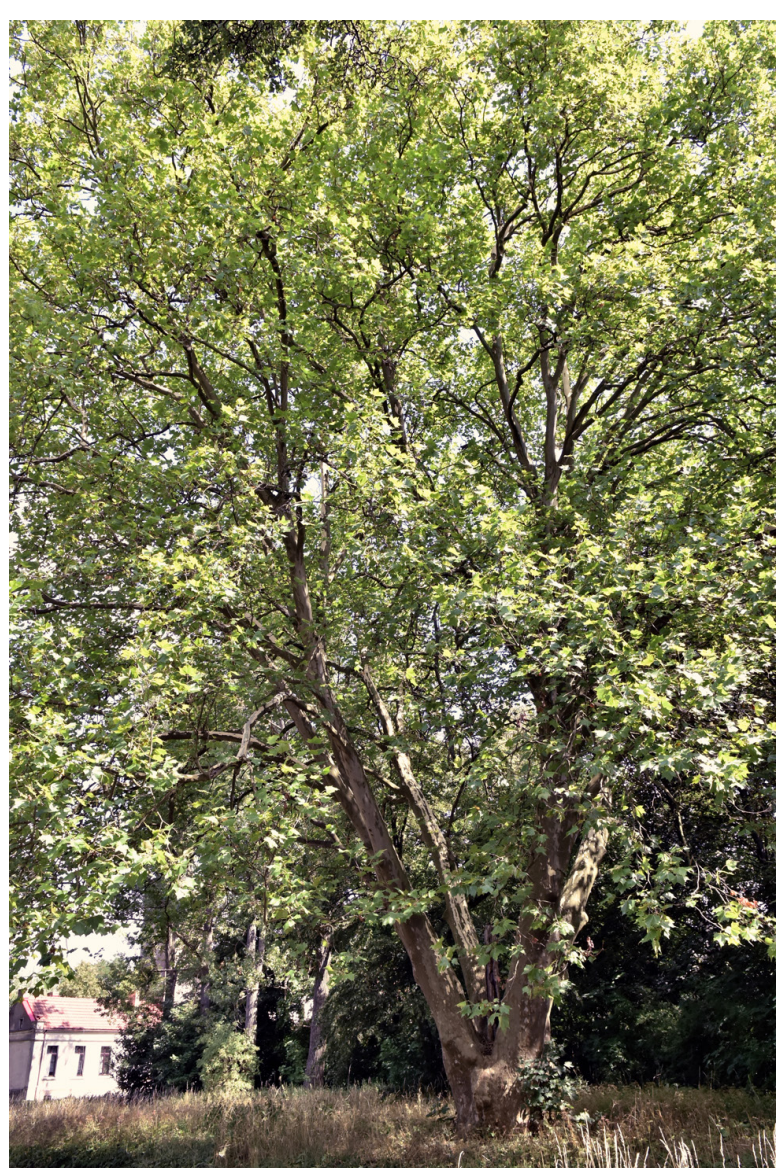

Fig. 6. Platanus $\times$ acerifolia (no. 573, Gorzewo, the Ryczywół commune, circumference $5.70 \mathrm{~m}$ ); photo M. Krajewski

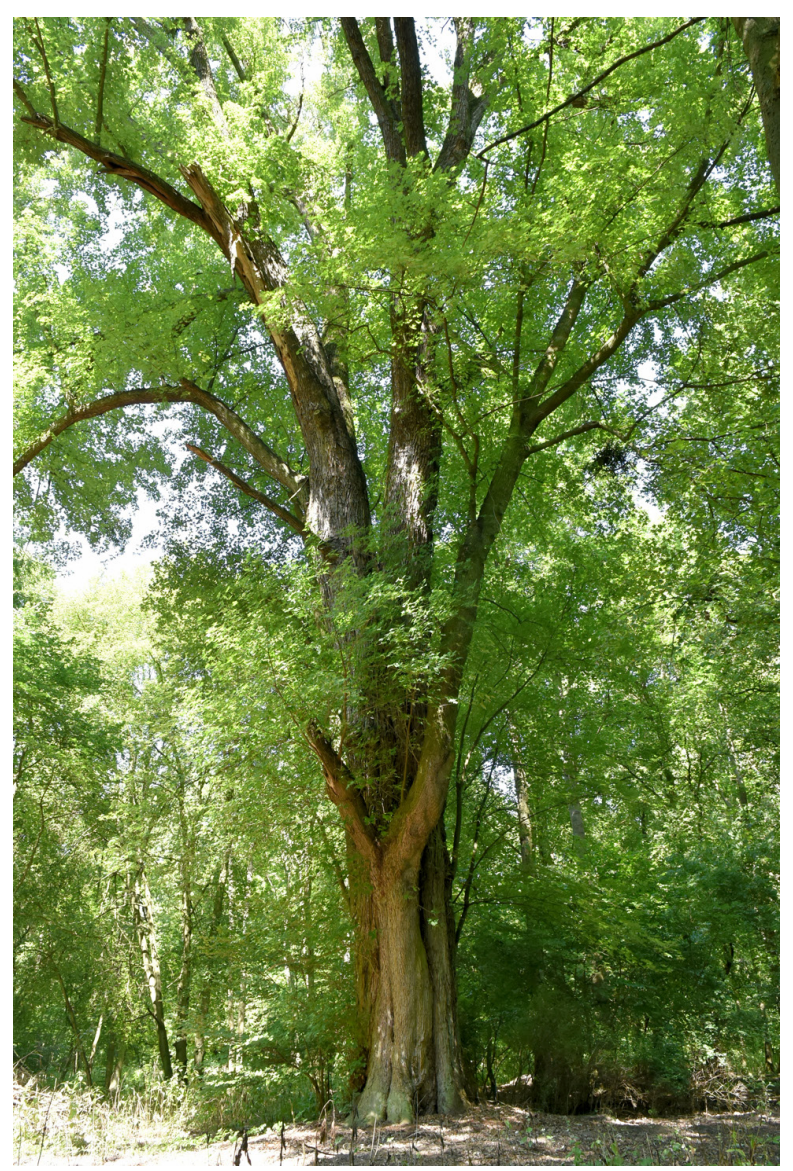

Fig. 7. Acer saccharinum (no. 139, Orłowo, the Ryczywół commune, circumference $5.20 \mathrm{~m}$ ); photo M. Krajewski 


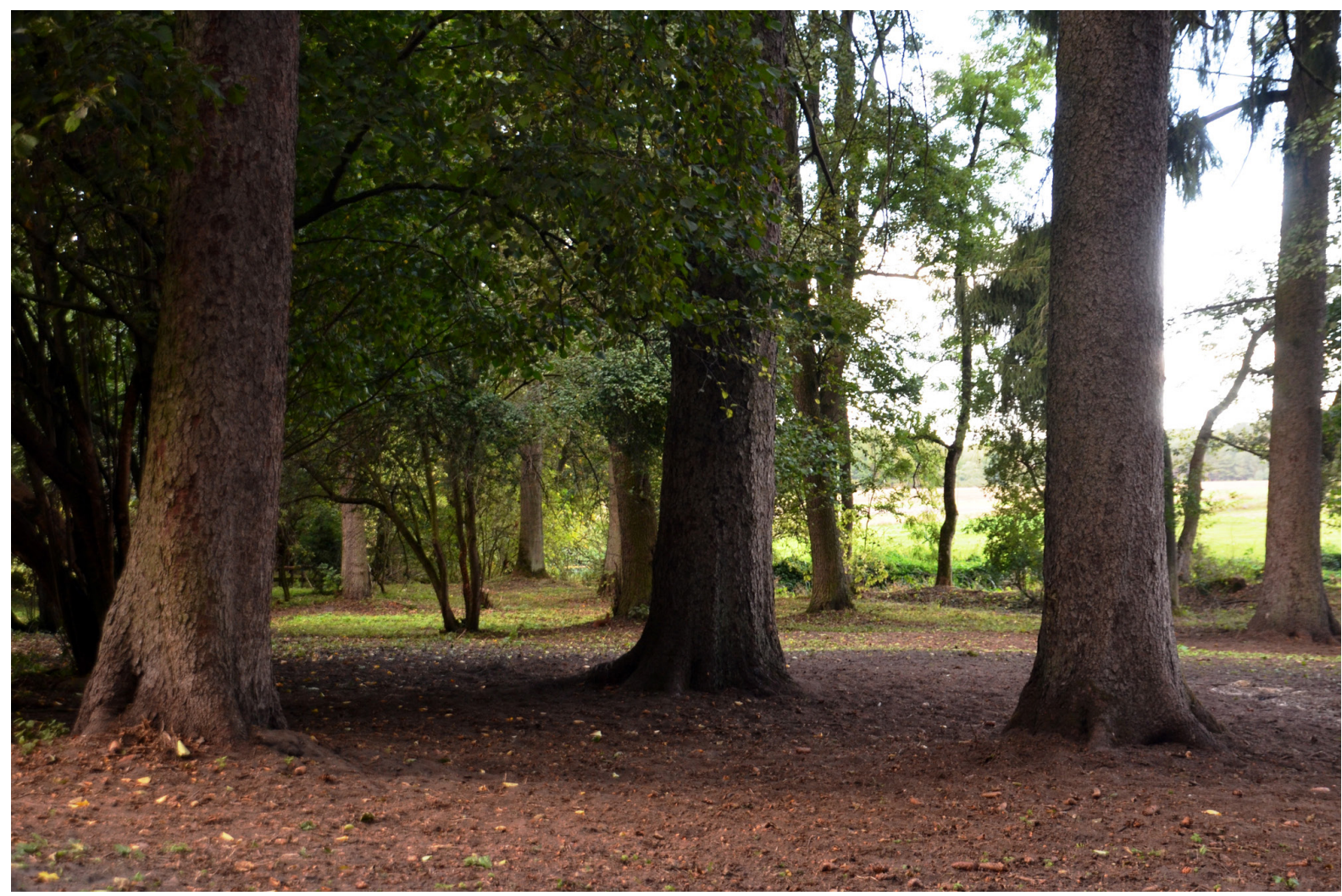

Fig. 8. A tree cluster monument - three Picea abies trees from the park in Niemieczkowo (no. 2008/3, the Oborniki commune, circumferences $1.75,1.95$ and $2.30 \mathrm{~m}$ ); photo W. Antkowiak

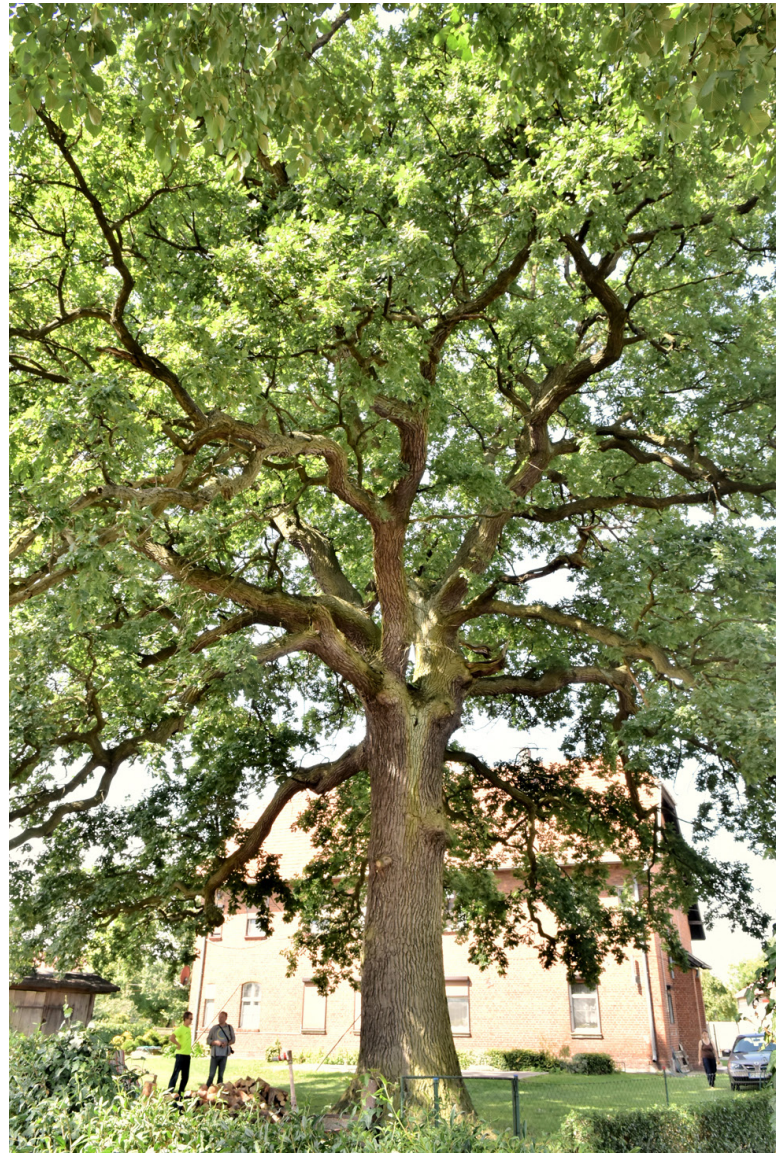

Fig. 9. Quercus robur (no. 138, Skrzetusz, the Ryczywół commune, circumference $4.78 \mathrm{~m}$ ); photo M. Krajewski

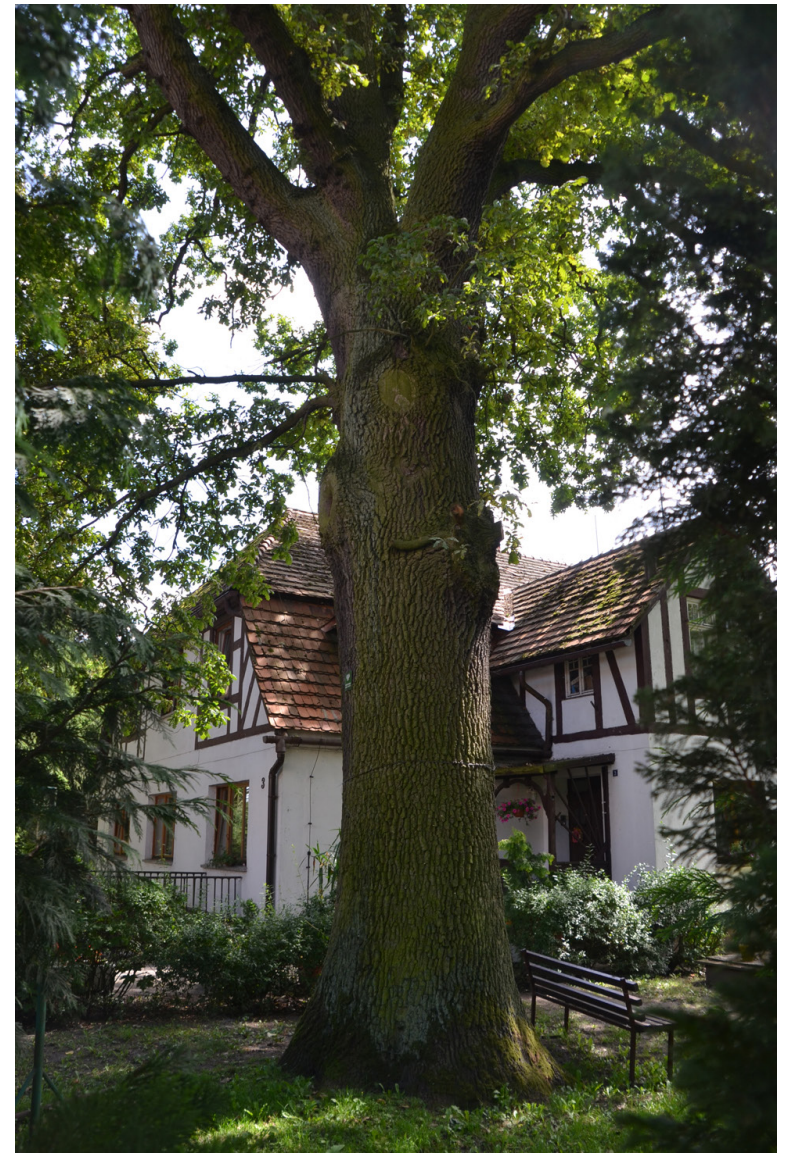

Fig. 10. Quercus robur (no. 424, Gorzewo, the Ryczywół commune, circumference $4.30 \mathrm{~m}$ ); photo W. Antkowiak 
cluded (Kusiak et al. 2008). A list not covered by legal protection is given below:

- a white poplar Populus alba L. - forest district Oborniki, compartment 276f, circumference 575 $\mathrm{cm}$,

- a black alder Alnus glutinosa Gaertn. - forest district Oborniki, compartment 855b, circumference $445 \mathrm{~cm}$,

- a crack willow Salix fragilis L. - forest district Kiszewko, compartment 600f, circumference 255 $\mathrm{cm}$,

- a crack willow Salix fragilis L. - forest district Niemieczkowo, compartment 866c, circumference $154 \mathrm{~cm}$,

- a common pear Pyrus communis L. - forest district Objezierze, compartment 268a, circumference $245 \mathrm{~cm}$,

- an apple tree Malus domestica Borkh. - forest district Objezierze, compartment 262b, circumference $179 \mathrm{~cm}$,

- an apple tree Malus domestica Borkh. - forest district Marylówka, compartment 531a, circumference $129 \mathrm{~cm}$,

- a grey alder Alnus incana L. - forest district Objezierze, compartment $277 \mathrm{c}$, circumference $150 \mathrm{~cm}$,

- a grey alder Alnus incana L. - forest district Wypalanki, compartment $540 \mathrm{~g}$, circumference 141 $\mathrm{cm}$,

- a singleseed hawthorn Crataegus monogyna Jacq. forest district Oborniki, compartment 835g, circumference $110 \mathrm{~cm}$,

- a singleseed hawthorn Crataegus monogyna Jacq. forest district Objezierze, compartment 300f, circumference $101 \mathrm{~cm}$,

- a brid cherry tree Padus avium Mill. - forest district Objezierze, compartment 277c, circumference $107 \mathrm{~cm}$.

In Poland almost $75 \%$ all trees covered by legal protection as natural monuments are oaks and lime trees (GRZYWACZ 2002), while in the surveyed area these species account for $47.5 \%$ all trees. As it was reported by ZARZYŃSKI (2003), the percentage share of Quercus robur among monumental trees is $35.3 \%$, Q. petraea at $1.3 \%$ and Tilia cordata at $27.9 \%$. In the Wielkopolskie province the mean circumferences of trees from the above-mentioned species are 4.01, 3.81 and $4.13 \mathrm{~m}$, which classifies them as leading specimens in this respect.

When comparing statistical data (MAŁY RoczNIK... 2016) with the results of this study it may be observed that the data recorded in the surveyed area differ slightly from the national means. In the study area a total of 118 natural monuments were recorded, of which 110 were single trees $(93.2 \%)$, seven were tree clusters (5.9\%) and one was an avenue. In 2010 a total of 36293 natural monuments were registered in Poland, including 30059 (82.8\%) single trees, 3658 clusters $(10.1 \%)$ and 699 (1.9\%) avenues.
When analysing the dates of establishment of natural monuments for inventioried trees it was found that in the years 1950-1959 two (1.7\%) natural monuments were established, in the years 1960-1969 it was $16(13.6 \%)$ natural monuments, in the period 1980-1989-5 (4.2\%), in the years 1990-1999-22 (18.6\%), whereas $73(61.9 \%)$ trees were assigned the status of natural monuments in the years 2000-2008 (in the period 1970-1979 no natutal monuments were established in Poland). According to BrzeźniaK (1995) from 1960 to 1993 the number of natural monuments increased 4.6 -fold. On the national scale the greatest number of natural monuments (7090) was established in the years 1980-1990, while in the period 1960-1970 it was only 1722 natural monuments. In turn, GrzYwacz (2002) reported that in 2000 in comparison to the status of 1960 the number of single such trees and clusters increased 7-fold, while for that of avenues it was 9.2-fold.

\section{REFERENCES}

BRzeźniaK E. (1995): Rozwój sieci pomników przyrody w Polsce w ostatnim 35-leciu. Chrońmy Przyrodę Ojczystą 3: 7-15.

Conwentz H. (1904): Die Gefährdung der Naturdenkmäler und Vorschläge zu ihrer Erhaltung. Gebrüder Borntraeger, Berlin.

GrzYwacz A. (2002): Drzewa - pomniki przyrody. Las Polski 5: 19-21.

Harabin Z. (1996): Ochrona drzew pomnikowych w Polsce. Komunikaty Dendrologiczne. Ochrona Krajobrazu 2(24): 5-12.

Iwanowski C., Łuczak Z., Mikstacki B. (1966): Przegląd wielkopolskich zabytków przyrody. Państwowe Wydawnictwo Rolnicze i Leśne, Warszawa.

Kulesza W. (1928): Wykaz drzew i krzewów godnych ochrony w Poznańskiem i na Pomorzu. Ochrona Przyrody 7: 9-45.

Kusiak B., Węgiel A., Borkowski K., Danielewicz W. (2008): Najgrubsze drzewa Lasów Państwowych. Centrum Informacyjne Lasów Państwowych, Warszawa.

MAŁY RoczNIK Statystyczny 2016 (2016). Główny Urząd Statystyczny, Warszawa.

OlaczeK R. (1978): Funkcje parków wiejskich. In: V. Mikhajjlov, K. Zabierowski (eds). Ochrona i kształtowanie środowiska przyrodniczego. Vol. 2. PWN, Warszawa.

PACYNiAK C., Smólski S. (1973). Drzewa godne uznania za pomniki przyrody oraz stan dotychczasowej ochrony drzew pomnikowych w Polsce. Roczniki Akademii Rolniczej w Poznaniu 67: 41-66.

Pfunl F. (1904): Bäume und Wälder der Provinz Posen. Ein Bericht, im Aufträge der Naturwissenschaftlichen Abteilung veröffentlicht vom Herausgeber. Zeitschrift der Naturwissenschaftlichen Abteilung 10(2-6), Botanik 10(2-2): 1-184. 
Pfuhl F. (1908): Bäume und Wälder der Provinz Posen, Nachtrag 1. Zeitschrift der Naturwissenschaftlichen Abteilung 14(3), Botanik 14(2): 6598.

Seneta W., Dolatowski J. (2008): Dendrologia. Wydawnictwo Naukowe PWN, Warszawa.

STECKI K. (1928): Osobliwe i godne ochrony drzewa z Poznańskiego, Pomorza i innych dzielnic Polski. Rocznik Polskiego Towarzystwa Dendrologicznego 2: 148-171.

Stecki K., Kulesza W. (1926): Z osobliwości dendrologicznych Wielkopolski. Rocznik Nauk Rolniczych i Leśnych 15: 68.

Środoń A. (1934): Inwentarz zabytkowych dębów w Polsce. Ochrona Przyrody 14: 78-110.

Środoń A. (1935a): Inwentarz zabytkowych lip w Polsce. Ochrona Przyrody 15: 95-129.
ŚRodoń A. (1935b). Uzupełnienie inwentarza zabytkowych dębów w Polsce. Ochrona Przyrody 15: 130-142.

ŚRODOŃ A. (1937): Materiały do inwentarza zabytkowych buków w Polsce. Ochrona Przyrody 17: 230-252.

Wodziczko A., Krawiec F., Urbański J. (1938): Pomniki i zabytki przyrody Wielkopolski. Wydawnictwo Okręgowego Komitetu Ochrony Przyrody na Wielkopolskę i Pomorze, 8. Poznań.

ZARZYŃSKI P. (2003): Liczba pomnikowych dębów i lip w Polsce. Rocznik Dendrologiczny 51: 57-60.

For citation: AntKowiak W., Ludian J. (2016): Natural monuments and monumental trees in the $\mathrm{Ob}$ orniki and Ryczywół communes. Steciana 20(4): 219-231. doi: 10.12657/steciana.020.023 